\title{
PENGARUH DOSIS PEMBERIAN BEKATUL TERHADAP PERUBAHAN SIFAT KIMIA TANAH SAWAH DI DUKUH PRANTI DESA SRIHARDONO KECAMATAN PUNDONG KABUPATEN BANTUL
}

\author{
Nursawia Latuamury \\ Dosen Universitas Nani Bili Nusantara
}

Diterima: 8 April 2017. Dipublikasikan: 1 Juni 2017

\begin{abstract}
Abstrak
Tujuan dari penelitian ini adalah untuk mengetahui pengaruh pemberian bekatul pada perubahan sifat fisik dan kimia tanah sebelum dan sesudah perlakuan. Metode yang digunakan dalam penelitian ini adalah eksperimen dengan melakukan beberapa perlakuan pemberian bekatul pada berbagai dosis di lahan sawah, kemudian tanah diambil sebelum perlakuan dan sesudah dari setiap perlakuan yang diambil secara komposit untuk dilakukan analisis di Laboratorium. Sifat-sifat fisika tanah sebelum penanaman padi dianalisis mencakup tekstur 3 fraksi (metode pipet), berat volume (metode lilin) dan berat jenis tanah (metode piknometer). Analisis sifat-sifat kimia sebelum penanaman padi meliputi: $\mathrm{pH} \mathrm{H}_{2} \mathrm{O}, \mathrm{KPK}, \mathrm{C}$-organik, N-total, $\mathrm{N}$-tersedia, P-tersedia, dan K-tersedia. Hasil dari penelitian menunjukkan analisis sifat kimia tanah sebelum dan sesudah pemberian bekatul, tidak mengalami perubahan bahkan mengalami penurunan pada beberapa perlakuan karena di duga adanya pengaruh dari penyerapan oleh tanaman. Pemberian bekatul memberikan pengaruh pada perbaikan sifat fisik tanah yang diawali dengan perubahan struktur tanah yang dapat dideteksi dari variabel berat volume, berat jenis dan porositas total tanah.
\end{abstract}

\section{PENDAHULUAN}

Peningkatan jumlah penduduk setiap tahun merupakan suatu permasalah yang selalu dihadapi pemerintan karena adanya peningkatan penduduk akan menyebabkan adanya peningkatan akan kebutuhan pangan khususnya padi. Laju pertambahan penduduk mencapai rata-rata 1,7 persen per tahun, sehingga kebutuhan per kapita sebanyak $134 \mathrm{~kg}$, pada tahun 2006 Indonesia mampu menghasilkan padi sebanyak 54,45 juta ton, tahun 200757,16 juta ton dan tahun 200860,28 juta ton gkg untuk mencukupi kebutuhan beras nasional (Pedoman Pelaksanaan SL. PTT, 2009). Kebutuhan pangan kita sangat tergantung pada ketersediaan lahan yang digunakan sebagai area budidaya tanaman pertanian, sehingga peningkatan penggunnaan lahan pertanian terus bertambah setiap tahunnya. Untuk mengurangi pembukaan terhadap lahan baru, berbagai upaya dilakukan pemerintah seperti program intensifikasi pertanian.
Program intensifikasi pertanian lebih diarahkan pada peningkatan produksi pangan tanpa perlu dilakukan perluasan pada areal pertanian tetapi diperlukan teknologi masukan yang tinggi untuk meningkatkan produktivitas tanaman.

Teknologi revolusi hijau berupa inovasi jenis (varietas) unggul banyak menghilangkan plasma nutfah lokal dan ketergantungan petani terhadap kebutuhan bibit. Teknologi revolusi hijau membutuhkan investasi besar berupa pupuk, pestisida, herbisida, jenis unggul, air serta energi. Pemakaian pupuk kimia tanpa pupuk anorganik menyebabkan lahan semakin tandus sehingga setiap musim tanam memerlukan input asupan luar semakin banyak. Teknologi revolusi hijau menyebabkan terjadinya degradasi lingkungan.

Hal ini erat kaitannya dengan adanya dampak negatif sistem budidaya dengan asupan luar yang tinggi. Pemberian pupuk (N) berlebihan dapat memacu pertumbuhan gulma sehingga hasil padi 
menurun karena persaingan dengan gulma meningkat. Tekanan kebutuhan sesaat itu ternyata dalam jangka panjang memunculkan akibat samping diantaranya adanya penurunan kesuburan tanaman dan pertumbuhan gulma yang tidak terkendali sehingga mengganggu kesetimbangan ekosistem lingkungan budidaya pertanian. Akibat negatif yang dialami usaha pertanian secara verbal diistilahkan mengurangi sustainability sektor pertanian, tidak mendukung sifat lestari, tidak berwawasan lingkungan, utamanya memang disebabkan oleh cara-cara bercocok tanam yang mengandalkan masukan bahan kimia buatan.

\section{Tujuan Penelitian}

Tujuan dari penelitian ini adalah untuk mengetahui pengaruh pemberian bekatul pada perubahan sifat fisik dan kimia tanah sebelum dan sesudah perlakuan.

\section{TATA LAKSANA PENELITIAN Tempat dan Waktu}

. Pengambilan sampel tanah pada Demplot Tanaman Padi Sawah dengan Perlakuan sebelum dan sesudah pemberian bekatil di lahan milik petani di Dukuh Pranti Desa Srihardono Kecamatan Pundong Kabupaten Bantul Yogyakarta. Penelitian berlangsung selama 5 bulan. Analisis tanah di Laboratorium Ilmu Tanah UGM.

\section{Metode Penelitian}

Penelitian ini dilakukan secara eksperimen dengan melakukan percobaan pada beberapa perlakuan untuk melihat pengaruh dari pemberian bekatul terdapa perbahan sifat fisik dan kimia pada lahan sawan milik petani di di Dukuh Pranti Desa Srihardono Kecamatan Pundong Kabupaten Bantul Yogyakarta. Perlakuan pemberian bekatul yang dilakukan pada percobaan lapangan dengan rancangan faktorial $3 \times 3$ +2 kontrol disusun dalam pola dasar Rancangan Acak Kelompok Lengkap dengan perlakuan sebagai berikut :

1. Perlakuan waktu pemberian bekatul:

$\mathrm{W}_{1}=$ Seminggu sebelum tanam

$\mathrm{W}_{2}=$ Saat tanam

$\mathrm{W}_{3}=$ Seminggu setelah tanam
2. Dosis bekatul yang digunakan:
$\mathrm{D}_{3}=300 \mathrm{~kg} \cdot \mathrm{ha}^{-1}$
$\mathrm{D}_{6}=600 \mathrm{~kg} \cdot \mathrm{ha}^{-1}$
$\mathrm{D}_{9}=900 \mathrm{~kg} \cdot \mathrm{ha}^{-1}$

3. Kontrol yang digunakan:

$\mathrm{K}_{1}=$ tanpa bekatul gulma di kendalikan

$\mathrm{K}_{2}=$ tanpa bekatul gulma tidak dikendalikan

\section{Pengambilan sampel tanah, analisi tanah dan bekatul}

Pengambilan contoh tanah pertama dilakukan setelah pengolahan tanah sebelum aplikasi perlakuan. Sedangkan pengambilan contoh tanah kedua dilakukan pada saat panen. Pada tiap petak diambil contoh tanah dari 5 titik secara acak, kemudian dicampur menjadi contoh tanah komposit.

Sifat-sifat fisika tanah sebelum penanaman padi dianalisis mencakup tekstur 3 fraksi (metode pipet), berat volume (metode lilin) dan berat jenis tanah (metode piknometer). Analisis sifat-sifat kimia sebelum penanaman padi meliputi: $\mathrm{pH} \mathrm{H}_{2} \mathrm{O}, \mathrm{KPK}, \mathrm{C}$-organik, N-total, Ntersedia, P-tersedia, dan K-tersedia. Penentuan $\mathrm{pH} \mathrm{H}_{2} \mathrm{O}$ dengan $\mathrm{pH}$ meter (perbandingan aquades : tanah $=1: 2,5$ ), KPK dengan metode ekstrak amonium asetat $\mathrm{pH} \mathrm{7,0;} \mathrm{C-organik} \mathrm{dengan} \mathrm{metode}$ Walkey dan Black, N-total dengan metode Kjeldahl, N-tersedia dengan metode Rajendra dan Prasad, P-tersedia ditentukan dengan metode ekstrak Olsen, K-tersedia ditentukan dengan cara ekstraksi asam lemah amonium asetat dan flamefotometer (Prawirowardoyo, 1987).

Sifat-sifat tanah setelah panen yang dianalisis mencakup berat jenis dan berat volume tanah. Sifat-sifat kimia tanah yang diamati mencakup $\mathrm{pH} \mathrm{H}_{2} \mathrm{O}$ (perbandingan aquades : tanah $=1: 2,5$ ), C-organik, kadar $\mathrm{N}$-total dan $\mathrm{N}$-tersedia, P-tersedia, serta Ktersedia. Metode yang digunakan sama dengan metode analisis tanah sebelum tanam.

Bekatuls sebelum digunakan dianalisis kandungan unsur-unsur yang terkandung yang meliputi: $\mathrm{N}$ total, $\mathrm{pH}$, Kadar air, $\mathrm{C} / \mathrm{N}$ ratio, dan asam-asam fenolat 
yang merupakan zat penghambat pertumbuhan gulma.

\section{HASIL DAN PEMBAHASAN \\ Hasi Penelitian \\ Kondisi lahan penelitian}

\section{a. Keadaan tanah sebelum penelitian}

Berdasarkan analisis sifat fisika

tanah awal, tanah di lokasi penelitian bertekstur geluh. Fraksi padat tanah yang bertekstur geluh terdiri atas fraksi pasir, debu dan lempung. Di lain pihak, ada dua (2) sifat kimia tanah yang menguntungkan, yaitu $\mathrm{pH} \quad \mathrm{H}_{2} \mathrm{O}$ netral dan KPK yang tergolong tinggi. Dengan demikian, tanah tersebut mempunyai kesuburan potensial yang tinggi.

Tabel 4.1 Hasil analisis tanah sebelum tanam

\begin{tabular}{|c|c|c|c|}
\hline Sifat Fisika & \multicolumn{3}{|c|}{ Sifat Kimia } \\
\hline Variabel Pengamatan & Nilai & Variabel Pengamatan & Nilai \\
\hline Berat Volume $\left(\mathrm{g} . \mathrm{cm}^{-3}\right.$ & 1,37 & $\mathrm{pH} \mathrm{H}_{2} \mathrm{O}$ & $6,60^{\mathrm{n}}$ \\
\hline Berat Jenis $\left(\mathrm{g} \cdot \mathrm{cm}^{-3}\right)$ & 1,86 & $\mathrm{KPK}\left(\mathrm{c} \mathrm{mol}(+) \mathrm{kg}^{-1}\right)$ & $15,09^{\text {st }}$ \\
\hline Porositas Total (\%) & 26,34 & C-org $(\%)$ & $1,64^{\mathrm{r}}$ \\
\hline Fraksi Lempung (\%) & 16,11 & N-total (\%) & $0,09^{\mathrm{r}}$ \\
\hline Fraksi Debu $(\%)$ & 48,34 & N-tersedia (ppm) & 6,96 \\
\hline Fraksi Pasir (\%) & 35,55 & P-tersedia $\left(\mathrm{ppm} \mathrm{P}_{2} \mathrm{O}_{5}\right)$ & $2,98^{\mathrm{sr}}$ \\
\hline Kelas Tekstur USDA & Geluh & K-tersedia $\left(\mathrm{c} \mathrm{mol} \mathrm{kg}^{-1}\right)$ & $0,46^{\mathrm{s}}$ \\
\hline
\end{tabular}

Keterangan : $\mathrm{m}=$ masam, $\mathrm{sr}=$ sangat rendah, $\mathrm{r}=$ rendah, dan $\mathrm{t}=$ tinggi

Sumber : Laboratorium Balai Pengembangan Teknologi Pertanian Yogyakarta, 2009.

Berdasarkan Tabel di atas juga ditunjukkan bahwa hasil analisis C-organik, $\mathrm{N}$-total tergolong rendah, P-tersedia sangat rendah dan K-tersedia sedang. Kondisi ini menjadi faktor pembatas pertumbuhan tanaman budidaya, khususnya padi. Dalam hal ini, dapat dikatakan bahwa kesuburan aktual tanah ini rendah. Oleh karena itu, diperlukan usaha-usaha untuk meningkatkan kesuburan aktual tanah sehingga budidaya padi di lokasi tersebut dapat berhasil dengan baik. Salah satu usaha tersebut adalah dengan pemupukan.

\section{b. Keadaan tanah setelah penelitian}

Hasil analisis sifat-sifat fisika tanah yang diamati setelah panen disajikan pada Tabel 4.2, sedangkan sifat-sifat kimia tanah ditampilkan pada Tabel 4.3.

Tabel 4.2 Sifat fisika tanah setelah panen

\begin{tabular}{|c|c|c|c|}
\hline $\begin{array}{c}\text { Perlakuan } \\
\left(\mathrm{kg} \cdot \mathrm{ha}^{-1}\right)\end{array}$ & Berat Volume $\left(\mathrm{g} \cdot \mathrm{cm}^{-3}\right)$ & Berat Jenis $\left(\mathrm{g} \cdot \mathrm{cm}^{-3}\right)$ & $\begin{array}{c}\text { Porositas } \\
(\%)\end{array}$ \\
\hline W1D3 & 1,24 & 1,88 & 33,98 \\
\hline W1D6 & 1,37 & 1,82 & 24,62 \\
\hline W1D9 & 1,39 & 1,24 & 31,25 \\
\hline W2D3 & 1,29 & 1,93 & 33,21 \\
\hline W2D6 & 1,26 & 1,98 & 36,49 \\
\hline W3D9 & 1,36 & 1,58 & 13,89 \\
\hline W3D3 & 1,31 & 1,94 & 32,6 \\
\hline W3D6 & 1,27 & 1,87 & 31,96 \\
\hline W3D9 & 1,36 & 1,98 & 31,39 \\
\hline K1 & 1,39 & 1,86 & 25,06 \\
\hline K2 & 1,23 & 1,80 & 22,05 \\
\hline
\end{tabular}


${ }^{*}$ komposit 3 unit percobaan, tanpa ulangan.

Berdasarkan pengamatan sifat-sifat tanah setelah panen tersebut, diketahui bahwa berat volume tanah tidak mengalami perubahan yang berarti. Di lain pihak, berat jenis dan porositas tanah cenderung meningkat. Porositas tanah menggambarkan besarnya volume pori per volume bongkah tanah. Telah diketahui bahwa bahan organik sangat berperan dalam pembentukan agregat tanah. Peningkatan porositas tanah merupakan salah satu tanda adanya perbaikan sifat fisika tanah akibat pemberian bahan organik berupa bekatul.

Berat volume tanah menggambarkan berat bongkah (dengan pori-pori tanah) per satuan volume tanah. Sedangkan berat jenis tanah menggambarkan berat padatan tanah (tanpa pori-pori tanah) per satuan volume tanah. Perbaikan struktur tanah pada tanah berat (seperti vertisol) akan meningkatkan volume pori-pori tanah sehingga porositasnya meningkat. Peningkatan porositas tanah ini disebabkan oleh peningkatan bahan organik tanah dalam hal ini bekatul, seperti disajikan oleh Tabel 4.2.

Sifat-sifat kimia tanah setelah panen juga terlihat mengalami perubahan. Hasil pengamatan sifat-sifat kimia tanah setelah panen disajikan pada Tabel 4.3. Tingkat kemasaman tanah cenderung menurun setelah penanaman padi. Hal ini ditunjukkan oleh $\mathrm{pH} \mathrm{H}_{2} \mathrm{O}$ tanah awal senilai
6,60 sedangkan $\mathrm{pH} \quad \mathrm{H}_{2} \mathrm{O}$ tanah setelah panen berkisar 5,64-5,90. C-organik tanah setelah panen cenderung meningkat, nilai rata-ratanya sebesar $2,16 \%$ dibanding dengan $\mathrm{C}$-organik tanah awal yang nilainya $1,64 \%$. N-total tanah cenderung mengalami perubahan dari nilai sebesar $0,09 \%$ menjadi $0,11 \%$ setelah panen. Namun peningkatan $\mathrm{N}$ total yang tergantung pada bekatul sebesar 1,15 justru membantu menaikkan kandungan $\mathrm{N}$ total di dalam tanam sehingga justru memberikan kontribusi positif terhadap pertumbuhan tanaman. $\mathrm{P}$ dan $\mathrm{K}$ tersedia setelah panen sangat bervariasi bila dibandingkan dengan $\mathrm{P}$ dan $\mathrm{K}$ tersedia awal. Rata-rata $\mathrm{P}$ tersedia tanah setelah panen senilai 3,51 ppm, atau sedikit meningkat bila dibandingkan dengan $\mathrm{P}$ tersedia tanah awal senilai 2,98 ppm. Sedangkan $\mathrm{K}$ tersedia mengalami penurunan dari $0,46 \mathrm{c}$ mol. $\mathrm{kg}^{-1}$ pada tanah awal menjadi rata-rata $0,35 \mathrm{cmol} \cdot \mathrm{kg}^{-1}$ pada tanah setelah panen.

Kemasaman tanah menurun setelah pertanaman padi. Bekatul yang diberikan merupakan penyumbang bahan organik tanah. Bekatul dalam tanah akan segera terdekomposisi. Salah satu hasil akhir proses dekomposisi bekatul atau bahan organik yang lain adalah asam-asam organik. Asam organik, seperti tersirat dalam namanya, bersifat asam sehingga berpotensi menurunkan $\mathrm{pH}$ tanah.

Tabel 4.3 Sifat-sifat kimia tanah setelah panen ${ }^{*}$

\begin{tabular}{|l|c|c|c|c|c|c|}
\hline $\begin{array}{c}\text { Perlakuan } \\
\left(\mathrm{kg.ha}^{-1}\right)\end{array}$ & $\mathrm{pH} \mathrm{H}_{2} \mathrm{O}$ & $\begin{array}{c}\mathrm{C}- \\
\mathrm{org}(\%)\end{array}$ & N-total (\%) & $\begin{array}{c}\text { N-tsd } \\
(\mathrm{ppm})\end{array}$ & $\begin{array}{c}\text { P- } \\
\text { tsd(ppm) }\end{array}$ & $\begin{array}{c}\text { K-tsd } \\
(\mathrm{ppm})\end{array}$ \\
\hline W1D3 & 5,85 & 1,29 & 0,09 & 7,01 & 4,86 & 0,49 \\
\hline W1D6 & 5,90 & 2,42 & 0,12 & 1,55 & 1,67 & 0,48 \\
\hline W1D9 & 5,64 & 2,78 & 0,28 & 1,55 & 5,43 & 0,25 \\
\hline W2D3 & 5,73 & 1,81 & 0,90 & 7,74 & 1,47 & 0,19 \\
\hline W2D6 & 5,86 & 2,41 & 0,12 & 3,10 & 3,42 & 0,54 \\
\hline W2D9 & 5,79 & 2,42 & 0,90 & 5,42 & 5,94 & 0,59 \\
\hline W3D3 & 5,79 & 1,73 & 0,90 & 5,41 & 4,82 & 0,07 \\
\hline W3D6 & 5,77 & 2,15 & 0,60 & 2,33 & 3,71 & 0,37 \\
\hline W3D9 & 5,73 & 2,17 & 0,90 & 5,42 & 3,46 & 0,35 \\
\hline K1 & 5,67 & 1,39 & 0,12 & 0,78 & 1,47 & 0,17 \\
\hline K2 & 5,56 & 1,26 & 0,02 & 0,78 & 0,42 & 0,11 \\
\hline
\end{tabular}

*) komposit 3 unit percobaan, tanpa ulangan 
Apabila Tabel 4.3 dicermati lebih lanjut, $\mathrm{pH}$ tanah perlakuan tanpa bekatul juga mengalami penurunan dari nilai 6,60 menjadi 5,56-5,67. Jadi, penurunan $\mathrm{pH}$ selain disebabkan oleh perlakuan bekatul, juga disebabkan oleh adanya tanaman padi yang tumbuh pada lahan percobaan selama musim tanam. Seperti halnya pada tanaman pada umumnya, sel-sel pada jaringan akar padi melakukan respirasi selama terjadinya proses pertumbuhan dan perkembangan tanaman. Oksigen yang dibutuhkan akar disuplai dari bagian tajuk melalui jaringan aerenkim karena oksigen tidak tersedia pada tanah tergenang. Respirasi merupakan reaksi perombakan substrat untuk menghasilkan ATP dengan $\mathrm{CO}_{2}$ sebagai produk sampingan. $\mathrm{CO}_{2}$ yang dihasilkan oleh respirasi akar akan dilepaskan ke mintakat perakaran. Selanjutnya $\mathrm{CO}_{2}$ dapat bereaksi dengan air, dengan persamaan reaksi setimbang $\mathrm{CO}_{2}+\mathrm{H}_{2} \mathrm{O} \leftrightarrow \mathrm{H}^{+}+\mathrm{HCO}_{3}^{-}$. Penurunan $\mathrm{pH}$ tanah terjadi karena adanya penambahan ion $\mathrm{H}^{+}$.

Kadar C-organik adalah variabel sifat kimia tanah selain $\mathrm{pH}$ yang diamati setelah panen. Berdasarkan hasil analisis tanah pada Tabel 4,3, kadar C-organik tanah pada perlakuan bekatul (900 dan 600 kg.ha ${ }^{-1}$ ) lebih tinggi dibandingkan dengan C-organik pada perlakuan kontrol. Kadar Corganik juga meningkat bila dibandingkan dengan kadarnya pada tanah sebelum penanaman.

Kadar C-organik tanah awal, tergolong rendah Hal ini menunjukkan bahwa aplikasi bekatul dapat meningkatkan kadar bahan organik tanah, sehingga dapat memperbaiki sifat kimia tanah yang bersangkutan. Perlakuan bekatul 900 dan $600 \mathrm{~kg} \cdot \mathrm{ha}^{-1}$ masing-masing dapat meningkatkan kadar C-organik tanah sebesar 2,42\% dan 2,41\% dibandingkan dengan kontrol manual dengan kadar $\mathrm{C}$ organik 1,39 \% dan kontrol tanpa pengendalian gulma dengan kadar Corganik $1,26 \%$. N-total sebelum dan setelah penanaman cenderung tidak mengalami perubahan atau sedikit mengalami peningkatan.

Pemberian bekatul sekaligus berperan sebagai bahan organik dapat memperbaiki sifat fisika tanah, yang diawali dari perubahan struktur tanah. Pada jenis tanah yang sama, perbedaan struktur tanah sangat mungkin terjadi apabila kadar bahan organiknya berbeda. Bahan organik dapat berfungsi sebagai bahan perekat antar partikel-partikel tanah. Pada tanah dengan kadar bahan organik tinggi, struktur tanahnya lebih baik bila dibandingkan dengan tanah dengan kadar bahan organik rendah. Perbedaan struktur tanah tersebut dapat dideteksi dari variabel berat volume, berat jenis dan porositas total tanah .

\section{Pembahasan}

Penggenangan dapat menyebabkan berbagai perubahan sifat kimia, fisikokimia (elektrokimia), biologi tanah yang mempengaruhi penyediaan dan pengambilan hara oleh padi sawah. Perubahan sifat-sifat kimia tersebut hampir selalu dipengaruhi oleh proses reduksioksidasi secara biologis sebagai akibat dari kurangnya $\mathrm{O}_{2}$, dalam proses respirasi beberapa mikroorganisme beberapa unsur atau ionnnya harus bertindak sebagai penerima elektron. Dalam keadaan tidak tergenang $\mathrm{O}_{2}$ bertindak sebagai penerima elektron, tetapi dalam keadaan tergenang ketika $\mathrm{O}_{2}$ sangat berkurang, maka senyawasenyawa mineral atau unsur-unsur atau kedua-duanya harus bertindak sebagai penerima elektron.

Pada tanah tergenang mikroorganisme anaerob fakultatif dan obligat menggunakan $\mathrm{NO}^{3-}, \mathrm{Mn}^{4+}, \mathrm{Fe}^{3+}$, $\mathrm{SO}_{4}^{2-}, \mathrm{CO}_{2}$, dan $\mathrm{H}^{+}$sebagai penerima elektron dalam respirasinya sehingga mereduksi $\mathrm{NO}_{3}{ }^{-}$menjadi $\mathrm{N}_{2}, \mathrm{Mn}^{4+}$ menjadi $\mathrm{Mn}^{2+}, \mathrm{Fe}^{3+}$ menjadi $\mathrm{Fe}^{2+}, \mathrm{SO}_{4}{ }^{2-}$ menjadi $\mathrm{S}^{2-}$, $\mathrm{CO}_{2}$ menjadi $\mathrm{CH}_{4}$, dan $\mathrm{H}^{+}$menjadi $\mathrm{H}_{2}$ (Ponnamperuma, 1972; Patrick dan Reddy, 1978).

Setelah 2- 4 minggu mengalami perubahan yang cepat, proses tersebut menjadi stabil. Keadaan yang stabil ini memberi lingkungan yang baik untuk padi, karena ketersediaan hara cukup dan unsur beracun rendah. Kenaikan hasil padi sekitar 1 ton/ha dapat dicapai hanya dengan menunda penanaman padi hingga 2 minggu setelah penggenangan. Penggenangan menyebabkan pembentukan lapisan anaerobik dan aerobik, perubahan dalam 
potensial redoks, reduksi sekuensial dari sistem oksidasi-reduksi dan perubahan $\mathrm{N}$, $\mathrm{Mn}, \mathrm{Fe}, \mathrm{P}, \mathrm{S}$, dan unsur mikro.

Pemupukan dilakukan untuk meningkatkan kandungan hara tertentu dalam tanah sehingga kebutuhan tanaman akan hara tersebut dapat terpenuhi. Unsur nitrogen $(\mathrm{N})$ adalah unsur makro yang sangat penting bagi tanaman padi. Urea adalah pupuk $\mathrm{N}$ yang sudah lama digunakan oleh petani padi. Namun demikian, pemupukan $\mathrm{N}$ yang berlebihan atau tidak berimbang dipercaya sebagai penyebab pelandaian (levelling off) produksi padi. Pelandaian tersebut umumnya menjadi alasan petani untuk meningkatkan dosis $\mathrm{N}$ yang diberikan. Di lain pihak, harga urea di pasaran cenderung meningkat akhir-akhir ini. Telah diketahui bahwa sebenarnya kadar minimal bahan organik dalam tanah adalah $2 \%$ supaya usaha tani dapat berkelanjutan. Padahal dalam penelitian ini, berdasarkan hasil analisis awal, kadar bahan organik tanahnya hanya sebesar 1,64\%. Kadar bahan organik yang rendah ini juga dapat menjadi penyebab pelandaian produksi padi.

Pemberian bekatul sekaligus berperan sebagai bahan organik dapat memperbaiki sifat fisika tanah, yang diawali dari perubahan struktur tanah. Pada jenis tanah yang sama, perbedaan struktur tanah sangat mungkin terjadi apabila kadar bahan organiknya berbeda. Bahan organik dapat berfungsi sebagai bahan perekat antar partikel-partikel tanah. Pada tanah dengan kadar bahan organik tinggi, struktur tanahnya lebih baik bila dibandingkan dengan tanah dengan kadar bahan organik rendah. Perbedaan struktur tanah tersebut dapat dideteksi dari variabel berat volume, berat jenis dan porositas total tanah .

\section{Kesimpulan}

Kesimpulan dari penelitian ini adalah :

1. Analisis sifat kimia tanah sebelum dan sesudah pemberian bekatul, tidak mengalami perubahan bahkan mengalami penurunan pada beberapa perlakuan karena di duga adanya pengaruh dari penyerapan oleh tanaman.

2. Pemberian bekatul memberikan pengaruh pada perbaikan sifat fisik tanah yang diawali dengan perubahan struktur tanah yang dapat dideteksi dari variabel berat volume, berat jenis dan porositas total tanah

\section{DAFTAR PUSTAKA}

Brady , N. C. 1989. The Nature and Properties of Soils. The Mac Millan Co, New York. 653 p.

Hardjowigeno, S., dan Rayes, L. 2005. Tanah Sawah: Karakteristik, Kondisi, dan Permasalahan Tanah Sawah di Indonesia. Bayumedia Publishing, Malang.

Ponnamperuma, F.N.1985. Chemical Kinetics of Wetland Rice Soils Relative to Soil Fertility. In: Wetlands Soil: Characterization, Clasification and Utilization, p.71-90. Los Banos, Laguna, Philippines: The International Rice Research Institute.

Singer, M.J. dan D.N. Munns. 1987. Soil: An Introduction. New York: Macmillan Publishing Company.

Suwastika, A.A.N.G. 2001. Biologi

Tanah. Jurusan Tanah, Fakultas Pertanian, UNUD, Denpasar. 